Ramni Jamnadass, Frank Place, Emmanuel Torquebiau, Eric Malézieux, Miyuki liyama, Gudeta W Sileshi, Katja Kehlenbeck, Eliot Masters, Stepha McMullin, John C Weber, Ian K Dawson 


\section{Agroforestry, food and nutritional security}

Ramni Jamnadass, Frank Place, Emmanuel Torquebiau, Eric Malézieux, Miyuki liyama, Gudeta W Sileshi, Katja Kehlenbeck, Eliot Masters, Stepha McMullin, John C Weber, lan K Dawson 
Correct citation: Jamnadass R, Place F, Torquebiau E, Malézieux E, Iiyama M, Sileshi GW, Kehlenbeck K, Masters E, McMullin S, Weber JC, Dawson IK. 2013. Agroforestry, food and nutritional security. ICRAF Working Paper No. 170. Nairobi, World Agroforestry Centre. DOI: http://dx.doi.org/10.5716/WP13054.PDF

This Working Paper is based on a document first presented at the International Conference on Forests for Food Security and Nutrition, FAO, Rome, 13-15 May 2013 (see Dawson et al. 2013 in accompanying references).

Titles in the Working Paper Series aim to disseminate interim results on agroforestry research and practices and stimulate feedback from the scientific community. Other publication series from the World Agroforestry Centre include: Technical Manuals, Occasional Papers and the Trees for Change Series.

Published by the World Agroforestry Centre

United Nations Avenue

PO Box 30677, GPO 00100

Nairobi, Kenya

Tel: +254(0)20 722 4000, via USA +1 6508336645

Fax: +254(0)20 722 4001, via USA +1 6508336646

Email: worldagroforestry@cgiar.org

Website: www.worldagroforestry.org

(C) World Agroforestry Centre, 2013

Working Paper No. 170

The views expressed in this publication are those of the authors and not necessarily those of the World Agroforestry Centre.

Articles appearing in the Working Paper Series may be quoted or reproduced without charge, provided their source is acknowledged. 


\section{The authors}

Ramni Jamnadass, Frank Place, Miyuki Iiyama, Gudeta Sileshi, Katja Kehlenbeck, Eliot Masters, Stepha McMullin and Ian Dawson work for the World Agroforestry Centre (ICRAF).

Emmanuel Torquebiau and Eric Malézieux work for CIRAD (Agricultural Research for Development), 34398 Montpellier CX5, France. 


\begin{abstract}
Agroforestry supports food and nutritional security through: (1) the direct provision of tree foods such as fruits and leafy vegetables and by supporting staple crop production; (2) by raising farmers' incomes through the sale of tree products and surplus staples; (3) by providing fuels for cooking; and (4) by supporting various ecosystem services such as pollination that are essential for the production of some food plants. While challenges for agroforestry in supporting food and nutritional security include policy and market constraints and an underinvestment in research, strong opportunities exist to promote multifunctional, climate-smart agricultural methods involving trees. To better support food and nutritional security, developments in agroforestry policies are required to reform tree and land tenure for the benefit of small-scale farmers, to reform how smallholders obtain agroforestry inputs such as tree seed and seedlings, and to recognise agroforestry as an important investment option. Research should support tree domestication to improve the yields of tree foods, and seek to enhance the complementarity and stability of food production in smallholders' agroforestry systems.
\end{abstract}

Keywords: fuelwood; indigenous food tree domestication; soil fertility replenishment; tree commodity crops 


\section{Acknowledgements}

We thank colleagues Jonathan Cornelius, Roger Leakey, Henry Neufeldt, Jim Roshetko, Hesti Tata and Barbara Vinceti for providing information during the compilation of this paper, as well as Flordeliza Bassiag, Timo Beiermann, Marie-Eve Ciparisse, Zakayo Kimuge, Gunasingham Mikunthan, Sisay Nune, Jimena Rábago Aguilar, Benjamin De Ridder, Noemi Stadler-Kaulich, Jennifer Schulz and other members of the Community for Climate Change Mitigation in Agriculture (an initiative of the Food and Agriculture Organization of the United Nations). 


\section{Contents}

1. Introduction

2. The benefits of agroforestry systems for food and nutritional security

2.1. Agroforestry for food production

2.2. Agroforestry for incomes to support access to food

2.3. Agroforestry, fuel and food

2.4. Agroforestry, ecosystem services, climate change and food

3. Challenges for agroforestry in supporting food and nutritional security

3.1. Policy constraints

3.2. Constraints in delivering tree products to markets

3.3. Underinvestment in research

4. Options to increase the role of agroforestry in supporting food and nutritional security

4.1. Policy opportunities

4.2. A three-step approach for agroforestry to support food and nutritional security

4.3. Planning for climate change

5. Recommendations

6. References 


\section{Figures}

Figure 1. A fruit tree 'portfolio' consisting of nine tree species fruiting at different times of the year

Figure 2. Maize yields in five districts in Malawi with and without the intervention of the Agroforestry Food Security Programme

Figure 3. Vegetation maps for East Africa, showing the current baseline (a) and predicted vegetation (b) at 2080

\section{Boxes}

Box 1. Developing domestic markets for tree foods: the case of smallholder fruit production in sub-Saharan Africa

Box 2. The Malawi Agroforestry Food Security Programme, household food security and dietary diversity

Box 3. Integrating markets and cultivation to support the sustainable development of a new tree commodity crop: the case of allanblackia

Box 4. The participatory tree domestication approach in Cameroon: description and impacts 


\section{Introduction}

Agroforestry - the integration of trees with annual crop cultivation, livestock production and other farm activities - is a series of land management approaches practised by more than 1.2 billion people worldwide. Integration increases farm productivity when the various components occupy complementary niches and their associations are managed effectively (Steffan-Dewenter et al. 2007). Agroforestry systems may range from open parkland assemblages, to dense imitations of tropical rainforests such as home gardens, to planted mixtures of only a few species, to trees planted in hedges or on boundaries of fields and farms, with differing levels of human management of the various components. Agroforestry systems provide a variety of products and services that are important locally, nationally and globally (Garrity 2004); but their role is not always fully acknowledged in development policies and practices, reflecting the difficult-to-measure, diverse pathways by which trees affect people's lives. Women who are unable to afford high-cost technologies due to severe cash and credit constraints often favour relatively low-input agroforestry options (Kiptot and Franzel 2012).

With recent world food price spikes, anthropogenic climate change concerns, and the challenge of a growing global human population, the roles of farms and forests in supporting food availability and nutritional security have returned centre-stage in politics and development. In order to provide context for the on-going discussions concerning the importance of different potential interventions to support food and nutritional security, in this Working Paper we assess the direct and indirect roles of agroforestry. In the following section we discuss agroforestry's importance in providing food directly, in providing incomes to support access to food, in providing fuel for cooking, and through ecosystem service provision. Many of the examples presented are from sub-Saharan Africa, a region of particular concern where nine of the 20 nations with the highest burden of child under-nutrition worldwide are found (Bryce et al. 2008). Subsequent sections provide an overview of the current challenges that agroforestry faces in better supporting food and nutritional security, and discuss opportunities for action to improve the present situation. For further information on the roles of trees and agroforestry in food provision, earlier summaries on the topic should not be neglected (e.g., Arnold 1990, Hoskins 1990).

\section{The benefits of agroforestry systems for food and nutritional security}

\subsection{Agroforestry for food production}

Solving the problems of food and nutritional security requires among other interventions a range of interconnected agricultural approaches, including improvements in staple crop productivity, the biofortification of staples, and the cultivation of a wider range of edible plants that provide fruits, nuts, vegetables, etc., for more diverse diets (Frison et al. 2011). Potential for the diversification of crop production lies in the great range of lesser-used indigenous foods found in forests and wooded lands that are often richer in micronutrients, fibre and protein than staple crops (Leakey 1999, Malézieux 2013). Although such foods have traditionally been harvested from forests and woodlands, access to these resources is declining with deforestation and forest degradation (FAO 2010). In this context, cultivation provides an alternative resource. Moreover, the yield and quality of production can be improved during cultivation if attention is given to genetic improvement and the adoption of efficient farm management methods, making planting an attractive option: for many wild trees, including indigenous fruits, a two-fold yield improvement or more is possible through genetic selection (Jamnadass et al. 2011).

When bringing trees from the wild into cultivation it is essential to increase yields: if indigenous trees are perceived as relatively unproductive, agriculture in deforested areas is likely to be dominated by staple crops and agro-biodiversity will be reduced (Sunderland 2011). Some food-providing trees and 
palms, especially fruit-producing ones, have been managed by people in a transition from the wild to cultivation in farmland for millennia, resulting in complex agroforestry systems that contain many different foods; for other tree foods, the move to domestication is much more recent and is based on scientific inquiry (Torquebiau 1984, Clement 2004). A combination of indigenous and exotic tree foods in agroforestry systems supports nutrition, the stability of production, and farmers' incomes (see box 1 for an African example). Mixtures of fruit trees that spread production provide a yearround supply of important nutrients (fig. 1).

Box 1. Developing domestic markets for tree foods: the case of smallholder fruit production in sub-Saharan Africa

Exotic and indigenous fruits cultivated and managed in agroforestry systems are important foods in Africa, as illustrated by household surveys. In Kenya, for example, a 2004 survey of more than 900 households found that over 90\% grew fruit, with at least one-quarter growing banana (Musa spp.), avocado (Persea americana) and mango (Mangifera indica). Over two-thirds of households that reported fruit production harvested from at least four fruit species, while over half sold some fruit. Similarly, in a 2009 survey of more than 1100 rural households in Malawi, at least half consumed mango and/or papaya (Carica papaya) and one-third consumed oranges (Citrus sinensis), among other fruit, most of which were harvested from their own farms.

Despite this, the average consumption of fruit and vegetables in sub-Saharan Africa is significantly lower than the minimum recommended daily intake of $400 \mathrm{~g}$ per person. One reason is that poor households that have to buy food focus on the purchase of staples such as maize and rice that provide relatively cheap and 'concentrated' sources of carbohydrate to meet basic energy needs, leaving only a small fraction of the family budget to spend on other foods. Expenditure analysis shows, however, that as households' incomes increase, the purchase of fruit increases, meaning that as incomes grow in the region due to economic development, domestic markets for fruit are predicted to grow by $\sim 5 \%$ per year over the next decade, when human population increases and urbanization are also taken into consideration. If production and delivery to consumers can be made more efficient, the potential for farmers to boost their incomes by meeting this increased demand is high. Women farmers in particular could benefit, since the harvesting and processing of fruit are often seen as their rather than men's activities. The incomes women receive are more likely to be used to purchase other foods for household consumption than incomes received by men, so families' diets should improve. As fruit production becomes more commercially profitable, however, businesses may be taken over by men.

One opportunity to influence child nutrition in the region is through home-grown school feeding programmes that link schools with local agricultural producers to promote more diverse, more nutritionally-balanced diets. Another is to supply the rapidly developing supermarket sector in the region, through the development of farmer producer groups that can negotiate with retailers and meet their quantity requirements and quality standards.

Source: adapted from Jamnadass et al. (2011).

As well as directly providing edible products, agroforestry trees support food production by a range of other means, including by providing shade and support for crops that need it, supporting animal production and improving soil fertility. Agroforestry has an important role in increasing the yields of vegetables that, with fruit, provide varied and nutritionally-balanced diets rather than calories alone (Susila et al. 2012). Trees can modify the microclimate for garden crops under harsh climates and support climbing plants such as yam (Maliki et al. 2012). In an initiative in East Africa, more than 200000 smallholder dairy farmers are growing fodder shrubs as supplementary feed. The typical increase in milk yield achieved is enabling smallholders to raise extra revenue from milk sales of more than USD 100 per cow per year, and allows farmers to provide more milk more efficiently to urban consumers (Place et al. 2009). 
Figure 1. A fruit tree 'portfolio' consisting of nine tree species fruiting at different times of the year. The portfolio shown is based on indigenous fruits in Malawi.

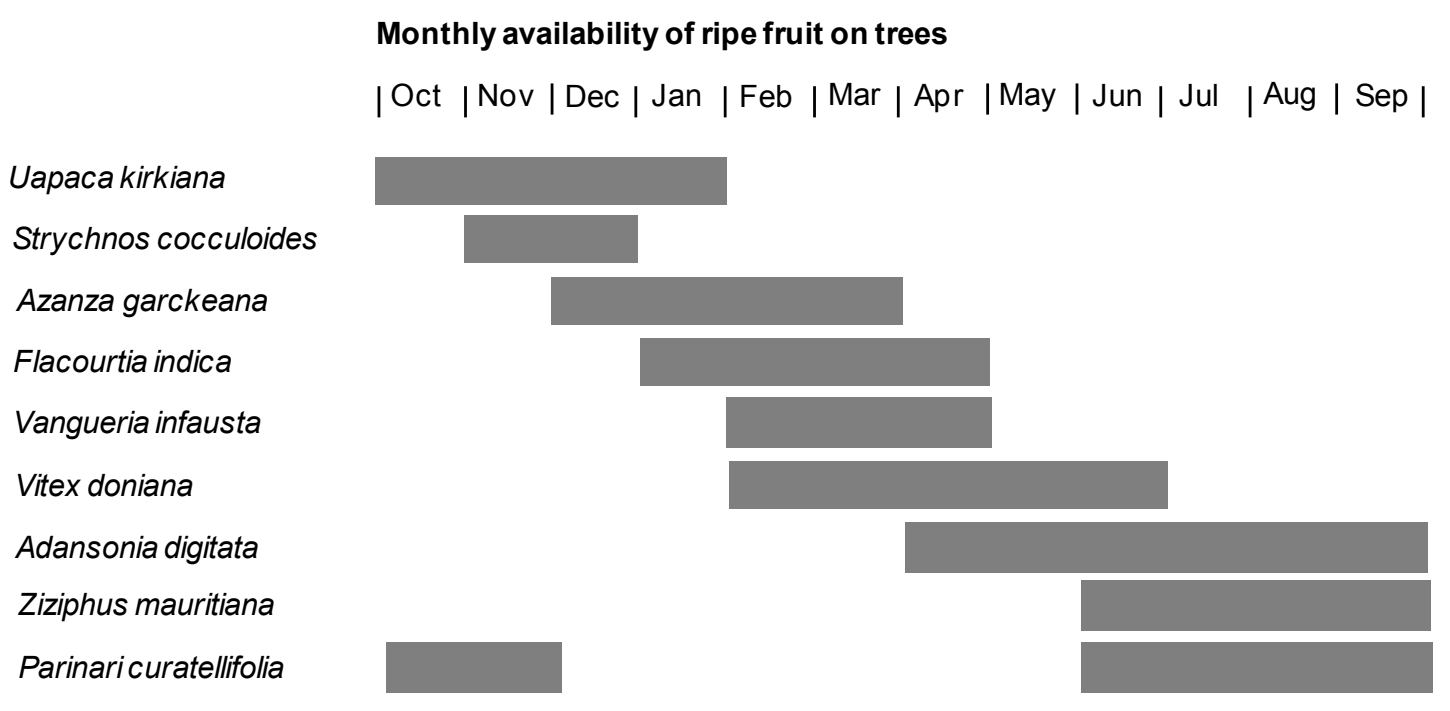

At least one species in the portfolio is ripe every month, including over traditional periods of hunger due to lulls in the production of staple crops (around January and February in Malawi). Based on the vitamin C content of the fruit of these trees and the recommended daily dietary intake, $\sim 50 \%$ of the vitamin $C$ needs of an adult man can be met by the daily consumption of $100 \mathrm{~g}$ of fruit pulp of one of two species, azanza (Azanza garckeana) or bush orange (Strychnos cocculoides), for the period November to March, with only $25 \mathrm{~g}$ daily of the vitamin C-rich baobab (Adansonia digitata) fruit pulp providing the requirement for the rest of the year, excluding October. Knowing the vitamin contents and phenologies of different fruits allows them to be combined appropriately in cultivation. Fruit production can also be spread across the year by cultivating late- and early-fruiting varieties of a particular species and/or by applying to only some trees pruning or coppicing practices to delay production. Source: modified from Jamnadass et al. (2011).

An analysis of more than 90 peer-reviewed studies on soil fertility improvement found consistent evidence of higher maize yields in Africa from planting nitrogen-fixing green fertilisers, including trees and shrubs, although the level of response varied by soil type and technology (Sileshi et al. 2008). As well as increasing average yields, the planting of trees as green fertilisers in southern Africa is able to stabilise crop production in drought years and during other extreme weather events, and improve crop rain use efficiency (Sileshi et al. 2011, 2012) (box 2 and fig. 2). This is important for food security in the context of climate change, which is increasing drought incidence in the region.

Supporting the regeneration of natural vegetation in agroforestry systems can also provide significant benefits for staple crops production. Farmer-managed natural regeneration (FMNR) of faidherbia (Faidherbia albida) and other leguminous trees in dryland agroforests (parklands) in semi-arid and sub-humid Africa is a good example. Since 1985, FMNR has been supported in Niger by a policy shift that awarded tree tenure to farmers (as well as by more favourable wetter weather); it has led to the 'regreening' of approximately 5 million hectares (Sendzimir et al. 2011). FMNR in the Sahel has led to improvements in sorghum and millet yields, and positive relationships have been observed with dietary diversity and household income (Place and Binam 2013). 
Box 2. The Malawi Agroforestry Food Security Programme, household food security and dietary diversity

Farmers in Malawi have recognised that low soil fertility is a major constraint on their ability to produce food. To address this through the planting of leguminous trees and shrubs, ICRAF and partners, with funding from Irish Aid, implemented the Malawi Agroforestry Food Security Programme, which between 2007 and 2011 reached $\sim 180000$ farmers. An external review of the programme in five districts surveyed 283 households that were beneficiaries (participants in the programme) and 200 that were not. In four of the five districts, maize yields were on average higher for beneficiaries than for non-beneficiaries (see fig. 2); on average, beneficiaries also had more food-secure months per year. Except in one district, dietary diversity (measured as the number of different types of food group consumed in a day) was also higher for beneficiaries, which could be attributed to the greater use of own fruit trees whose management (of existing trees) and planting were also promoted by the project, as well as to increases in incomes from farm sales of staples for further food purchases. The use of improved green fertiliser technologies has relevance beyond Malawi and the southern Africa region, and efforts to scale up appropriate methods are underway in other parts of Africa and beyond.

Source: adapted from CIE (2011)

Figure 2. Maize yields in five districts in Malawi with and without the intervention of the Agroforestry Food Security Programme. Figures are based on 283 beneficiaries and 200 non-beneficiaries distributed across districts.

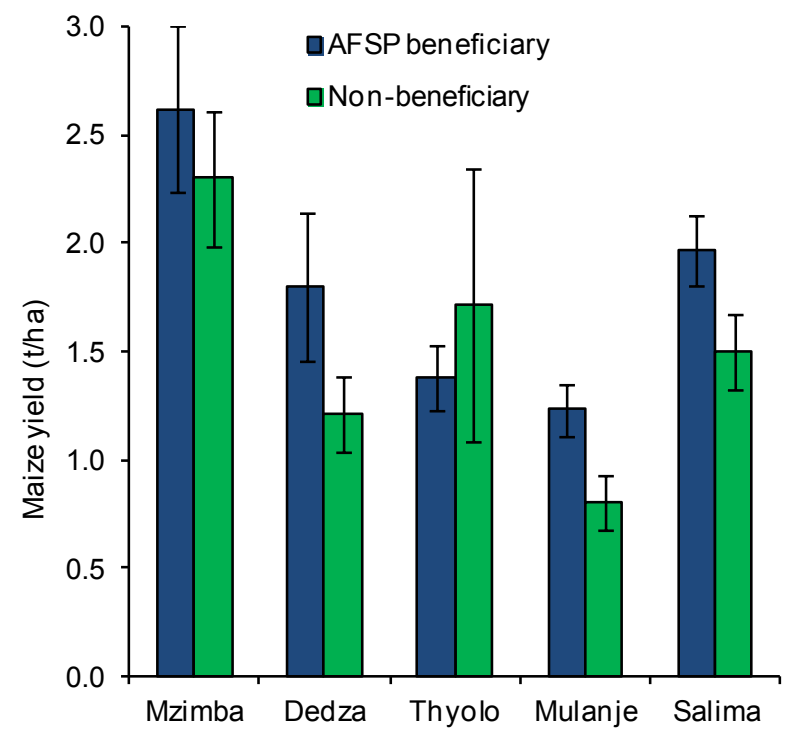

Note: bars represent 95\% confidence intervals; in three cases (Dedza, Mulanje and Salima) the difference between categories is statistically significant (see box 2 for further information).

\subsection{Agroforestry for incomes to support access to food}

Examples from Africa of widely traded agroforestry tree foods that support farmers' incomes include the indigenous semi-domesticated and widely cultivated fruit safou (Dacryodes edulis, Schreckenberg et al. 2006), the indigenous incipient domesticate shea nut (Vitellaria paradoxa, Masters and Addaquay 2011) and exotic mango. New commercial markets for fruit are developing in Africa as a result of recent investments by Coca Cola, Del Monte and others to source produce locally for juice manufacture. The production of timber and other agroforestry tree products for markets also provide incomes for food purchase. Many trees are cultivated to provide medicines from bark, leaves, roots, 
etc., which are sold to support incomes and are used for self treatment, supporting the health of communities along with the provision of healthy foods (Muriuki et al. 2012).

Market data recorded for agroforestry tree products are sparse, but information on export value is quantified for tree commodity crops such as palm oil (derived from oil palm, Elaeis guineensis), coffee (primarily from Coffea arabica), rubber (from Hevea brasiliensis), cocoa (from cacao, Theobroma cacao) and tea (primarily from Camellia sinensis). Each of these crops is grown to a significant extent by smallholders, as illustrated in Indonesia where, in 2011, small farms were estimated to contribute $42 \%, 96 \%, 85 \%, 94 \%$ and $46 \%$ of the country's total production area for palm oil, coffee, rubber, cocoa and tea, respectively (Government of Indonesia 2013). Unlike Indonesia, many countries do not formally differentiate between smallholder and larger-scale plantation production, but more than $67 \%$ of coffee produced worldwide is estimated to be from smallholdings (International Coffee Organization 2013), while the figure is $90 \%$ for cocoa (International Cocoa Organization 2013).

Taken together, the annual export value of the above five tree commodity crops is tens of billions of USD (FAO 2013a). Less clear is the proportion of the export value that accrues to smallholder producers, but often production constitutes a considerable proportion of farm takings. There is a danger, however, that the planting of commodities will result in the conversion of natural forest which contains important local foods - to agricultural land, and a risk that food crops will be displaced from farmland in a trend towards the growing of monocultures (e.g., oil palm, Danielsen et al. 2009). Buying food using the income received from a single commodity crop can also lead to food insecurity for farm households when payments are one-off, delayed or unpredictable in value. Monocultures also reduce resilience to shocks such as drought, flood and, often (although not always), the outbreak of pests and diseases. As a result, tree commodity crops are sometimes viewed sceptically within agricultural production-based strategies to improve nutrition (FAO 2012). For farmers who have too little land to cultivate enough food to meet their needs, however, incomes from tree commodity crops may be the only way to obtain sufficient food (Arnold 1990).

Mixed agroforestry regimes can help to avoid many of the negative effects described above by combining tree commodities in diverse production systems with locally important food trees, staple crops, vegetables and edible fungi. Such regimes include shade coffee and shade cocoa systems (Jagoret et al. 2011, 2012, Sustainable Cocoa Initiative 2013), which increase or at least do not decrease commodity yields and profitability (Clough et al. 2011). Such systems have often been traditionally practised but are now being actively encouraged through certification and other schemes by some international purchasers of tree commodity crops (Millard 2011). There are also opportunities to develop valuable new tree commodities that are compatible with other crops (box 3). Not all tree commodities are, however, amenable to production in diversified systems, for example, oil palm is not well suited (Donald 2004). 
Box 3. Integrating markets and cultivation to support the sustainable development of a new tree commodity crop: the case of allanblackia

The seed of allanblackia (Allanblackia spp.), found wild in the humid forests of Central, East and West Africa, yield edible oil with a significant potential in the global food market, especially as a 'hardstock' for the production of healthy spreads that are low in trans-fats. A private-public partnership known as Novella Africa is developing a sustainable allanblackia oil business that could be worth hundreds of millions of USD annually for local farmers. A supply chain for seed has been established in Ghana, Nigeria and the United Republic of Tanzania, based on harvesting by local communities in natural forests and from trees remaining in farmland after forest clearance. Currently, volumes are small (hundreds of tonnes) and oil is exported for food product development. At the same time, the tree is being brought into cultivation by improving seed handling and developing vegetative propagation methods, and through the selection of superior genotypes. Tens of thousands of seedlings and clones have so far been distributed to smallholders. The integration of allanblackia into smallscale cocoa farms is being promoted in West Africa to support more biodiverse and resilient agricultural landscapes. As allanblackia trees grow, cocoa trees provide the shade they need; when they are grown, they in turn will act as shade for cocoa. Cocoa and allanblackia provide harvests at different times of the year and when the allanblackia trees have matured - will spread farmers' incomes.

Source: adapted from Jamnadass et al. (2010)

\subsection{Agroforestry, fuel and food}

Traditional energy sources have received little attention in current energy debates, but firewood and charcoal from trees are crucial for the survival and well-being of perhaps two billion people, enabling them to cook food to make it safe for consumption and palatable and to release the energy within it (FAO 2008). In sub-Saharan Africa, the use of charcoal is still increasing rapidly, with the value of the charcoal industry there approximately USD 8 billion in 2007 (World Bank 2011). The charcoal industry is therefore important for food and nutritional security, because it produces both energy and income; with the increasing prices of 'modern' energy sources, this situation is unlikely to change for some time.

In poor households, firewood and charcoal are often burnt in open fires or poorly-functioning stoves with substantial emissions of pollutants (especially from firewood) that damage human health and may lead to the deaths of more than one million people annually worldwide, the majority women (Bailis et al. 2005). Fuel quality depends on the tree species being burnt, with poor families often using species that were traditionally avoided because of their harmful smoke or that were maintained for other products such as fruit (Brouwer et al. 1997).

Reduced access and increased prices of wood-based biomass have led to initiatives to promote agroforestry cultivation. Where smallholders practise agroforestry, less fuelwood needs to be purchased, there is less reliance on collecting from natural stands, and less time is involved in collection. This leaves more time for income-generating activities, especially for women who are usually the major fuelwood collectors (Thorlakson and Neufeldt 2012). Access to cooking fuel provides people with more flexibility in what they can eat, including foods with better nutritional profiles that require more energy to cook. The cultivation of woodlots allows the production of wood that is less harmful when burnt and has higher energy content. The use of better stoves - with greater efficiency - reduces greenhouse gas emissions relative to the energy generated for cooking purposes. 


\subsection{Agroforestry, ecosystem services, climate change and food}

Agroforestry trees provide important ecosystem services including: soil, spring, stream and watershed protection; animal and plant biodiversity conservation; and carbon sequestration and storage, all of which ultimately affect food and nutritional security (Garrity 2004). Individual farmers can be encouraged to preserve and reinforce functions that extend beyond their farms by payments for ecosystem services, but more important in determining their behaviour is the direct products and services they receive from trees (Roshetko et al. 2007a). An advantage of smallholder agroforestry systems is that they can perform wider services while directly supporting local production (Leakey 2010).

Appropriate combinations of crops, animals and trees in agroforestry systems can not only increase farm yields, but promote ecological and social resilience to change because the various components of a system and the interactions between them will respond in differing ways to disturbances. A diversity of species and functions within integrated production systems is therefore a risk reduction strategy, and agroforestry is recognised as an important component in climate-smart agriculture for both its adaptation and mitigation roles (Neufeldt et al. 2012). For example, soil fertility improvement technologies can stabilise crop yields in drought conditions (see section 2.1). In Niger, farmers explain that increasing the number of tree species per function insures them against 'function failure' in their farming systems because at least some species will provide each required function even in the driest years (Faye et al. 2011). In western Kenya, subsistence farmers practising agroforestry (e.g., for soil erosion control, improving soil fertility and fuelwood provision) identify more coping strategies when exposed to climate-related hazards than those who do not practise agroforestry (Thorlakson and Neufeldt 2012).

Kristjanson et al. (2012) explored the relationship between food security and farmer innovation in the context of changing circumstances, including climate variability, with farmers in Ethiopia, Kenya, Uganda and the United Republic of Tanzania. A strong positive relationship was demonstrated between food security and the adoption of new farming practices, although it was not possible to determine whether this was because innovative households are more food-secure as a result of innovation, or if more food-secure households are better placed to subsequently innovate. Many of the 700 surveyed households were practising agroforestry, but generally they were only planting small numbers of trees, suggesting that there is a need to understand why there has not been wider uptake of agroforestry. Possibly, the initial investment required before benefits are received from trees (perhaps some years after planting) is an important factor.

A diversity of trees in farmland and neighbouring natural forest fragments, where present, supports populations of pollinator species such as insects and birds that are essential for the production of many crops (Garibaldi et al. 2013). Many fruit tree species that are important as human foods rely on insect pollinators for their production (Klein et al. 2007), while diverse farms that provide an alternative habitat for pollinator communities can support the regeneration of food plants in neighbouring forests (Hagen and Kraemer 2010).

\section{Challenges for agroforestry in supporting food and nutritional security}

\subsection{Policy constraints}

Policy plays an important role in distinguishing countries and regions that have benefited from agroforestry from those that have not. Place et al. (2012) considered that there are three key policy areas in which constraints need to be overcome in order for agroforestry benefits to be distributed more widely. First, farmers need land and tree tenure. Where these are absent or contested, farmer involvement in tree-planting and management can be limited; but when they are assured, greater interest in agroforestry is stimulated (e.g., see section 2.1 for the case of FMNR in Niger). Land 
tenure rights are particularly important for agroforestry compared with other agricultural practices because of the relatively long period that may be required to realise benefits. Sometimes current policies on ownership have perverse effects, for example when regulations designed to control the harvesting, cutting or sale of tree products from forests are applied to farmland and limit the ability to use planted trees as substitutes for a wild resource.

Second, policies that determine how farmers obtain seeds, seedlings and clones of a wide range of tree species suitable for their various planting requirements are crucial (Lillesø et al. 2011). Current policies often slow the adoption of agroforestry, for example, by discriminating against small-scale entrepreneurial seed and seedling suppliers by providing NGOs and government extension services with funds to give free tree seed to farmers. Although well intentioned (to protect intellectual property, stop the introduction of potentially invasive species, etc.), laws to control germplasm flows internationally have also slowed smallholder access to appropriate planting material by, for example, limiting the transfer to Africa of superior cultivars of fruit trees developed in Asia.

Third, the current policy environment often does not recognise agroforestry as an attractive investment area in agriculture. For example, governments often subsidise the provision of artificial fertilisers to enhance staple crop yields, which discourages the adoption of improved fallow technologies that could ultimately increase staple crop production more cost effectively and sustainably. Another problem is the lack of attention given to tree products and services in data collection and therefore there is a lack of information on the value of agroforestry trees in supporting food and nutritional security (FAO 2013b).

\subsection{Constraints in delivering tree products to markets}

Markets for many tree products are poorly structured and coordinated (Roshetko et al. 2007b). This results in low and unstable returns to farmers and high prices for buyers of tree foods, which limits their consumption. Problems often cited by producers include the absence of a collective bargaining system, poor transport infrastructure, and the involvement of multiple intermediaries in the supply chain, all of which act to reduce farm prices (Jamnadass et al. 2011). For perishable goods such as fruit, the result is also high wastage along the supply chain and a failure to reach quality grades. Prevailing low returns mean that farmers struggle to afford inputs to improve their suboptimal farm management practices. Traders also face many problems such as poor roads, corrupt officials and the high cost of collecting tree products from geographically-scattered producers.

\subsection{Underinvestment in research}

There has been underinvestment in the development of new tree lines, cultivars, etc., that have high yields and provide quality products under smallholder production conditions. Until recently, for example, scientists mostly ignored the great potential for the improvement of indigenous fruit trees (Jamnadass et al. 2011). There are insufficient scientists working on bringing these indigenous species into cultivation in the tropics. For many indigenous food trees, only limited information is available on nutritional value, which can be expected to vary significantly even within species (Stadlmayr et al. 2013).

Although the benefits of agroforestry systems for responding to climate change are recognised, the great diversity of agroforestry landscapes and the sometimes long life cycles of trees and production systems mean that the most effective combinations of trees, staple crops, vegetables, animals, etc., and how to manage them together in particular environments, are often unknown (Neufeldt et al. 2012). A significant gap in knowledge is the effects of climate change on interactions between pollinators and plants in agroforestry systems. Asynchronies between tree-pollinator life cycles introduced by climate change could be particularly problematic for the yields of fruit trees, which otherwise constitute an important means to address malnutrition in the context of climate change (Dawson et al. 2011). 


\section{Options to increase the role of agroforestry in supporting food and nutritional security}

\subsection{Policy opportunities}

Guidelines were revised recently for policymakers to support agroforestry development (FAO 2013b). They recommend, for example, reforming unfavourable regulations, legal restrictions and restrictive financial mechanisms that inhibit the practice of agroforestry; clarifying land-use policy goals and regulations; elaborating new policies that acknowledge the role of trees on farms in development; and strengthening farmers' access to markets for tree products. Several countries, including Brazil, are developing or refreshing their agroforestry strategies in a participatory way with local communities, while the governments of China and India have embarked on ambitious programmes to increase tree cover outside forests. More attention should be given to food trees in such programmes. Some governments are setting minimum requirements for tree cover on farms. In Kenya, where a minimum of $10 \%$ cover has been set, the government has allocated funds to assist farmers to meet this requirement. Agroforestry is recognised under the United Nations Framework Convention on Climate Change as a key mitigation method within agriculture, and national climate change adaptation plans need to further embrace agroforestry as a climate-smart agricultural response.

\subsection{A three-step approach for agroforestry to support food and nutritional security}

Leakey (2010) described a step-wise multifunctional agricultural approach by which agroforestry can further support food and nutritional security: (1) support for soil fertility replenishment technologies is followed by (2) participatory tree domestication (box 4) and then (3) by entrepreneurship and value-addition to tree products. Potential interventions to benefit local communities in enterprise development include value chain analysis as undertaken, for example, by TechnoServe to improve banana markets in East Africa, where multiple brokerage levels deprived farmers of significant revenues (Milder 2008). Based on the TechnoServe analysis, smallholders were organised into producer business groups linked directly to wholesale banana buyers, which resulted in an increase in farmer income of over $80 \%$. In the context of food and nutritional security, 'nutrient-sensitive' value chains are required. This means improving nutritional knowledge and awareness among value-chain actors and consumers, focusing on promoting the involvement of women, and considering markets for a wider range of tree foods. By promoting tree food processing and other value additions, the nonfarm rural economy can also be stimulated.

\subsection{Planning for climate change}

One way in which food production through agroforestry practices can be adapted to climate change is by adjusting the tree composition of systems to take account of new environmental conditions (Dawson et al. 2011). Changes in composition can be made at the interspecific and intraspecific levels, the latter making use of within-species variations in growth and phenology in differing conditions. At the species level, the selection of 'generalist' food trees that grow well under varied conditions may be an important response, although this could result in a few highly adaptable exotics becoming dominant, which would be undesirable in providing a wide range of products and tree services. Another approach to planning for the future is to develop vegetation maps and explore how these will change under different climate scenarios (fig. 3). The best sites for planting particular tree species can be planned accordingly. At the intraspecific level, trials are required to measure genetic variation in climate-related traits, as was carried out recently by the Sahelian Fruit Trees initiative on fruit trees important to local people in the region (SAFRUIT 2013). 
Box 4. The participatory tree domestication approach in Cameroon: description and impacts

A new way of domesticating trees, referred to in the literature as the participatory approach, has been developed in Cameroon in the last decade as a close collaboration between scientists and farmers. The approach involves combining scientific advances with local communities' experiences to bring a range of valuable indigenous fruit trees into cultivation. An important aspect is using vegetative propagation methods to reduce the time to maturity and provide food and income more quickly to farmers. When applied in Cameroon, significant impacts have been achieved with the method. More fruit has been observed in farmers' diets for $\sim 50 \%$ of adopters and cropping systems have become more diverse. Smallholder incomes have increased from the sales of fruits and of fruit tree nursery stock (for planting by other farmers), and there has been a reduction in human migration from rural to urban areas because young people have stayed in villages to engage in new farming activities. The approach is being extended through the development of rural resource centres (RRCs) that train farmers in how to propagate and manage trees, and that provide fruit processing facilities and business training. RRCs also act as venues for farmers to meet and form associations that allow them to market their products and obtain services more effectively.

Source: adapted from Tchoundjeu et al. (2010).

\section{Recommendations}

To increase the role of agroforestry in food and nutritional security, we recommend the following:

- The current role of agroforestry tree products and services in supporting the food and nutritional security of the rural poor in different production systems should be better quantified. Where possible, this should be done separately for men, women and children, small-scale farmers, the landless poor and local traders. This will allow options for intervention to be better targeted.

- The development of agroforestry policy should not be confined to the agricultural or forest sectors; it needs a place of its own. Required reforms include targeting tree and land tenure, how farmers obtain the trees they plant, and the recognition of agroforestry as an investment option for food production.

- Research should support food tree domestication options appropriate for meeting smallholders' needs, and assess complementarity and resilience in agroforestry systems under climate change in the context of other global challenges to food and nutritional security. 
Figure 3. Vegetation maps for East Africa, showing the current baseline (a) and predicted vegetation (b) at 2080. Prediction for 2080 is based on change scenario A1B (model CCCMA-CGCM31).

a)

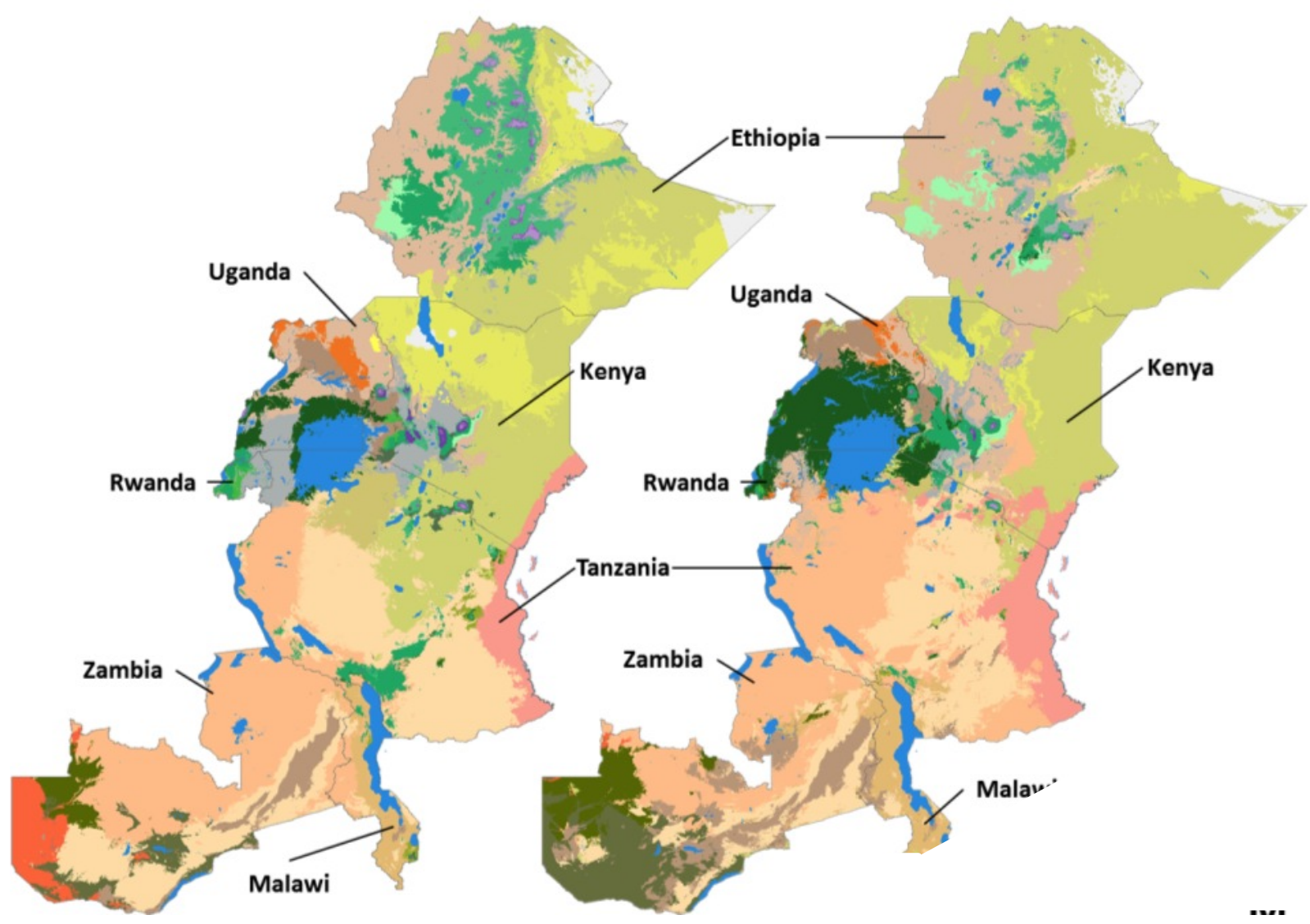

Note: Each vegetation type is assigned a specific colour (see www.vegetationmap4africa.org/). Maps suggest significant shifts in the suitability domains for tree species. Plans for agroforestry planting can take this into account.

\section{References}

Arnold J E M. 1990. Tree components in farming systems. Unasylva 160:35-42.

Bailis R, Ezzati M, Kammen D M. 2005. Mortality and greenhouse gas impacts of biomass and petroleum energy future in Africa. Science 308:98-103.

Brouwer I D, Hoorweg J C, van Liere M J. 1997. When households run out of fuel: responses of rural households to decreasing fuelwood availability, Ntcheu District, Malawi. World Development 25:255-266.

Bryce J, Coitinho D, Darnton-Hill I, Pelletier D, Pinstrup-Andersen P. 2008. Maternal and child under-nutrition: effective action at national level. The Lancet 371:510-526.

CIE. 2011. Evaluation of ICRAF's Agroforestry Food Security Programme (AFSP) 2007-2011. Final report submitted to IRISH AID. Lilongwe: Center for Independent Evaluations.

Clement C R. 2004. Fruits. In: G T Prance, M Nesbitt, eds. The cultural history of plants. London: Routledge, p.77-95. 
Clough Y, Barkmann J, Juhrbandt J, Kessler M, Wanger T C, Anshary A. 2011. Combining high biodiversity with high yields in tropical agroforests. Proceedings of the National Academy of Sciences of the USA 108:8311-8316.

Danielsen F, Beukema H, Burgess N D, Parish F, Brühl C A, Donald P F. 2009. Biofuel plantations on forested lands: double jeopardy for biodiversity and climate. Conservation Biology 23:348-358.

Dawson I K, Place F, Torquebiau E, Malézieux E, Iiyama M, Sileshi G W et al. 2013. Agroforestry, food and nutritional security. Background Paper No. 4. International Conference on Forests for Food Security and Nutrition. FAO, Rome, Italy, 13-15 May 2013. Rome: Food and Agriculture Organization of the United Nations.

Dawson I K, Vinceti B, Weber J C, Neufeldt H, Russell J, Lengkeek A G et al. 2011. Climate change and tree genetic resource management: maintaining and enhancing the productivity and value of smallholder tropical agroforestry landscapes. A review. Agroforestry Systems 81:67-78.

Donald P F. 2004. Biodiversity impacts of some agricultural commodity production systems. Conservation Biology 18:17-37.

FAO. 2008. The state of food and agriculture. Biofuels: prospects, risks and opportunities. Rome: Food and Agriculture Organization of the United Nations.

FAO. 2010. Global forest resources assessment 2010. FAO Forestry Paper No. 163. Rome: Food and Agriculture Organization of the United Nations.

FAO. 2012. Making agriculture work for nutrition: synthesis of guiding principles. Rome: Food and Agriculture Organization of the United Nations.

FAO. 2013a. FAOSTAT. http://faostat.fao.org (Accessed 8 April 2013).

FAO. 2013b. Advancing agroforestry on the policy agenda: a guide for decision-makers. Agroforestry Working Paper No.1. Rome: Food and Agriculture Organization of the United Nations.

Faye M D, Weber J C, Abasse T A, Boureima M, Larwanou M, Bationo A B et al. 2011. Farmers' preferences for tree functions and species in the West African Sahel. Forests, Trees and Livelihoods 20:113-136.

Frison E A, Cherfas J, Hodgkin T. 2011. Agricultural biodiversity is essential for a sustainable improvement in food and nutrition security. Sustainability 3:238-253.

Garibaldi L A, Steffan-Dewenter I, Winfree R, Aizen M A, Bommarco R, Cunningham S A et al. 2013. Wild pollinators enhance fruit set of crops regardless of honey bee abundance. Science 339:1608-1611.

Garrity D P. 2004. Agroforestry and the achievement of the Millennium Development Goals. Agroforestry Systems 61:5-17.

Government of Indonesia. 2013.

http://ditjenbun.deptan.go.id/cigraph/index.php/viewstat/komoditiutama (Accessed 8 April 2013).

Hagen M, Kraemer M. 2010. Agricultural surroundings support flower-visitor networks in an Afrotropical rain forest. Biological Conservation 143:1654-1663.

Hoskins M. 1990. The contribution of forestry to food security. Unasylva 160:3-13. 
International Cocoa Organization. 2013. http://www.icco.org (Accessed 8 April 2013).

International Coffee Organization. 2013. http://www.ico.org (Accessed 8 April 2013).

Jagoret P, Michel-Dounias I, Malézieux E. 2011. Long-term dynamics of cocoa agroforests: a case study in central Cameroon. Agroforestry Systems 81:267-278.

Jagoret P, Michel-Dounias I, Snoeck D, Todem Ngnogué H, Malézieux E. 2012. Afforestation of Savannah with cocoa agroforestry systems: a small-farm innovation in central Cameroon.

Agroforestry Systems 86:493-504.

Jamnadass R, Dawson I K, Anegbeh P, Asaah E, Atangana A, Cordeiro N et al. 2010. Allanblackia, a new tree crop in Africa for the global food industry: market development, smallholder cultivation and biodiversity management. Forests, Trees and Livelihoods 19:251-268.

Jamnadass R H, Dawson I K, Franzel S, Leakey R R B, Mithöfer D, Akinnifesi F K et al. 2011. Improving livelihoods and nutrition in sub-Saharan Africa through the promotion of indigenous and exotic fruit production in smallholders' agroforestry systems: a review. International Forest Review 13:338-354.

Kiptot E, Franzel S. 2012. Gender and agroforestry in Africa: a review of women's participation. Agroforestry Systems 84:35-58.

Klein A-M, Vaissière B E, Cane J H, Steffan-Dewenter I, Cunningham S A, Kremen C et al. 2007. Importance of pollinators in changing landscapes for world crops. Proceedings of the Royal Society of London, Series B 274:303-313.

Kristjanson P, Neufeldt H, Gassner A, Mango J, Kyazze F B, Desta S et al. 2012. Are food insecure smallholder households making changes in their farming practices? Evidence from East Africa. Food Security 4:381-397.

Leakey R R B. 1999. Potential for novel food products from agroforestry trees. Food Chemistry 64:114.

Leakey R R B. 2010. Agroforestry: a delivery mechanism for multi-functional agriculture. In: L R Kellimore, ed. Handbook on agroforestry: management practices and environmental impact. Environmental Science, Engineering and Technology Series. Hauppauge: Nova Science Publishers, p.461-471.

Lillesø J-P B, Graudal L, Moestrup S, Kjær E D, Kindt R, Mbora A et al. 2011. Innovation in input supply systems in smallholder agroforestry: seed sources, supply chains and support systems. Agroforestry Systems, 83:347-359.

Malézieux E. 2013. Editorial. Underutilized fruit trees in Africa. Special Issue. Revue Fruits (in press).

Maliki R, Cornet D, Floquet A, Sinsin B. 2012. Agronomic and economic performance of yam-based systems with shrubby and herbaceous legumes adapted by smallholders. Outlook on Agriculture 41:171-178.

Masters E, Addaquay J. 2011. Market study on prospects for shea products of Ghana origin. CHFSNV shea market assessment. Ottawa: Canadian Hunger Foundation.

Milder B. 2008. Closing the gap: reaching the missing middle and rural poor through value chain finance. Enterprise Development and Microfinance 19:301-316. 
Millard E. 2011. Incorporating agroforestry approaches into commodity value chains. Environmental Management 48:365-377.

Muriuki J, Franzel S, Mowo J, Kariuki P, Jamnadass R. 2012. Formalisation of local herbal product markets has potential to stimulate cultivation of medicinal plants by smallholder farmers in Kenya. Forests, Trees and Livelihoods 21:114-127.

Neufeldt H, Dawson I K, Luedeling E, Ajayi O C, Beedy T, Gebrekirstos A. et al. 2012. Climate change vulnerability of agroforestry. ICRAF Working Paper No. 143. Nairobi: World Agroforestry Centre.

Place F, Ajayi O C, Torquebiau E, Detlefsen G, Gauthier M, Buttoud G. 2012. Improved policies for facilitating the adoption of agroforestry. In: M Kaonga, ed. Agroforestry for biodiversity and ecosystem services: science and practice. Rijeka: InTech, p.113-128.

Place F, Binam J N. 2013. Economic impacts of farmer managed natural regeneration in the Sahel: end of project technical report for the Free University Amsterdam and IFAD. Nairobi: World Agroforestry Centre.

Place F, Roothaert R, Maina L, Franzel S, Sinja J, Wanjiku J. 2009. The impact of fodder trees on milk production and income among smallholder dairy farmers in East Africa and the role of research. ICRAF Occasional Paper No. 12. Nairobi: World Agroforestry Centre.

Roshetko J M, Lasco R D, Delos Angeles M S. 2007a. Smallholder agroforestry systems for carbon storage. Mitigation and Adaptation Strategies for Global Change 12:219-242.

Roshetko J M, Nugraha E, Tukan J C M, Manurung G, Fay C, van Noordwijk M. 2007b. Agroforestry for livelihood enhancement and enterprise development. In: S Djoeroemana, B Myers, J RussellSmith, M Blyth, I E T Salean, eds. Integrated rural development in East Nusa Tenggara, Indonesia. Proceedings of a workshop to identify sustainable rural livelihoods, Kupang, Indonesia, 5 to 7 April 2006. ACIAR Proceedings No.126. Canberra: Australian Centre for International Agricultural Research. p.137-148.

SAFRUIT. 2013. http://www.safruit.org (Accessed 8 April 2013).

Schreckenberg K, Awono A, Degrande A, Mbosso C, Ndoye O, Tchoundjeu Z. 2006. Domesticating indigenous fruit trees as a contribution to poverty reduction. Forests, Trees and Livelihoods 16:3551 .

Sendzimir J, Reij C P, Magnuszewski P. 2011. Rebuilding resilience in the Sahel: regreening in the Maradi and Zinder regions of Niger. Ecology and Society, 16 http://www.ecologyandsociety.org/vol16/iss3/art1/

Sileshi G W, Akinnifesi F K, Ajayi O C, Muys B. 2011. Integration of legume trees in maize-based cropping systems improves rain-use efficiency and yield stability under rain-fed agriculture. Agricultural Water Management 98:1364-1372.

Sileshi G W, Debusho L K, Akinnifesi F K. 2012. Can integration of legume trees increase yield stability in rainfed maize cropping systems in Southern Africa? Agronomy Journal 104:1392-1398.

Sileshi G, Akinnifesi F K, Ajayi O C, Place F. 2008. Meta-analysis of maize yield response to planted fallow and green manure legumes in sub-Saharan Africa. Plant and Soil 307:1-19. 
Stadlmayr B, Charrondière U R, Eisenwagen S, Jamnadass R, Kehlenbeck K. 2013. Nutrient composition of selected indigenous fruits from sub-Saharan Africa. Journal of the Science of Food and Agriculture (in press).

Steffan-Dewenter I, Kessler M, Barkmann J, Bos M M, Buchori D, Erasmi S. et al. 2007. Tradeoffs between income, biodiversity, and ecosystem functioning during tropical rainforest conversion and agroforestry intensification. Proceedings of the National Academy of Sciences of the USA 104:49734978.

Sunderland T C H. 2011. Food security: why is biodiversity important? International Forestry Review 13:265-274.

Susila A D, Purwoko B S, Roshetko J M, Palada M C, Kartika J G, Dahlia L et al., eds. 2012. Vegetable-agroforestry systems in Indonesia. Bangkok: World Association of Soil and Water Conservation; Nairobi: World Agroforestry Centre.

Sustainable Cocoa Initiative. 2013. http://cocoasustainability.com/ (Accessed 8 April 2013).

Tchoundjeu Z, Degrande A, Leakey R R B, Nimino G, Kemajou E, Asaah E. et al. 2010. Impacts of participatory tree domestication on farmer livelihoods in West and Central Africa. Forests, Trees and Livelihoods 19:217-234.

Thorlakson T, Neufeldt H. 2012. Reducing subsistence farmers' vulnerability to climate change: evaluating the potential contributions of agroforestry in western Kenya. Agriculture \& Food Security 1:15 http://www.agricultureandfoodsecurity.com/content/1/1/15

Torquebiau E. 1984. Man-made dipterocarp forest in Sumatra. Agroforestry Systems 2:103-127.

World Bank. 2011. Wood-based biomass energy development for sub-Saharan Africa: issues and approaches. Washington, DC: World Bank. 


\section{Working Paper Series}

\section{1}

124. An assessment of farm timber value chains in Mt Kenya area, Kenya

125. A comparative financial analysis of current land use systems and implications for the adoption of improved agroforestry in the East Usambaras, Tanzania

126. Agricultural monitoring and evaluation systems

127. Challenges and opportunities for collaborative landscape governance in the East Usambara Mountains, Tanzania

128. Transforming knowledge to enhance integrated natural resource management research, development and advocacy in the Highlands of Eastern Africa

129. Carbon-forestry projects in the Philippines: potential and challenges The Mt Kitanglad Range forest-carbon development

130. Carbon forestry projects in the Philippines: potential and challenges. The Arakan Forest Corridor forest-carbon project

131. Carbon-forestry projects in the Philippines: potential and challenges. The Laguna Lake Development Authority's forest-carbon development project

132. Carbon-forestry projects in the Philippines: potential and challenges. The Quirino forest-carbon development project in Sierra Madre Biodiversity Corridor

133. Carbon-forestry projects in the Philippines: potential and challenges. The Ikalahan ancestral domain forest-carbon development

134. The importance of local traditional institutions in the management of natural resources in the Highlands of Eastern Africa

135. Socio-economic assessment of irrigation pilot projects in Rwanda

136. Performance of three rambutan varieties (Nephelium lappaceum L.) on various nursery media

137. Climate change adaptation and social protection in agroforestry systems: enhancing adaptive capacity and minimizing risk of drought in Zambia and Honduras

138. Does value chain development contribute to rural poverty reduction? Evidence of asset building by smallholder coffee producers in Nicaragua

139. Potential for biofuel feedstock in Kenya

140. Impact of fertilizer trees on maize production and food security in six districts of Malawi.

\section{2}

141. Fortalecimiento de capacidades para la gestión del Santuario Nacional Pampa Hermosa: Construyendo las bases para un manejo adaptativo para el desarrollo local. Memorias del Proyect

142. Understanding rural institutional strengthening: A cross-level policy and institutional framework for sustainable development in Kenya

143. Climate change vulnerability of agroforestry

144. Rapid assessment of the inner Niger delta of Mali

145. Designing an incentive program to reduce on-farm deforestation in the East Usambara Mountains, Tanzania

146. Extent of adoption of conservation agriculture and agroforestry in Africa: the case of Tanzania, Kenya, Ghana, and Zambia

147. Policy incentives for scaling up conservation agriculture with trees in Africa: the case of Tanzania, Kenya, Ghana and Zambia

148. Commoditized or co-invested environmental services? Rewards for environmental services scheme: River Care program Way Besai watershed, Lampung, Indonesia 
149. Assessment of the headwaters of the Blue Nile in Ethiopia

150. Assessment of the uThukela Watershed, Kwazaulu

151. Assessment of the Oum Zessar Watershed of Tunisia

152. Assessment of the Ruwenzori Mountains in Uganda

153. History of agroforestry research and development in Viet Nam. Analysis of research, opportunities and gaps

154. REDD+ in Indonesia: a historical perspective

155. Agroforestry and Forestry in Sulawesi series: Livelihood strategies and land use system dynamics in South Sulawesi

156. Agroforestry and Forestry in Sulawesi series: Livelihood strategies and land use system dynamics in Southeast Sulawesi

157. Agroforestry and Forestry in Sulawesi series: Profitability and land-use systems in South and Southeast Sulawesi

158. Agroforestry and Forestry in Sulawesi series: Gender, livelihoods and land in South and Southeast Sulawesi

159. Agroforestry and Forestry in Sulawesi series: Agroforestry extension needs at the community level in AgFor project sites in South and Southeast Sulawesi, Indonesia.

160. Agroforestry and Forestry in Sulawesi series: Rapid market appraisal of agricultural, plantation and forestry commodities in South and Southeast Sulawesi

2013

161. Diagnosis of farming systems in the Agroforestry for Livelihoods of Smallholder farmers in Northwestern Viet Nam project

162. Ecosystem vulnerability to climate change: a literature review

163. Local capacity for implementing payments for environmental services schemes: lessons from the RUPES project in northeastern Viet Nam

164. Seri Agroforestri dan Kehutanan di Sulawesi: Agroforestry dan Kehutanan di Sulawesi: Strategi mata pencaharian dan dinamika sistem penggunaan lahan di Sulawesi Selatan

165. Seri Agroforestri dan Kehutanan di Sulawesi: Mata pencaharian dan dinamika sistem penggunaan lahan di Sulawesi Tenggara

166. Seri Agroforestri dan Kehutanan di Sulawesi: Profitabilitas sistem penggunaan lahan di Sulawesi Selatan dan Sulawesi Tenggara

167. Seri Agroforestri dan Kehutanan di Sulawesi: Gender, mata pencarian dan lahan di Sulawesi Selatan dan Sulawesi Tenggara

168. Seri Agroforestri dan Kehutanan di Sulawesi: Kebutuhan penyuluhan agroforestri pada tingkat masyarakat di lokasi proyek AgFor di Sulawesi Selatan dan Tenggara, Indonesia

169. Seri Agroforestri dan Kehutanan di Sulawesi: Laporan hasil penilaian cepat untuk komoditas pertanian, perkebunan dan kehutanan di Sulawesi Selatan dan Tenggara 
The World Agroforestry Centre is an autonomous, non-profit research organization whose vision is a rural transformation in the developing world as smallholder households increase their use of trees in agricultural landscapes to improve food security, nutrition, income, health, shelter, social cohesion, energy resources and environmental sustainability. The Centre generates science-based knowledge about the diverse roles that trees play in agricultural landscapes, and uses its research to advance policies and practices, and their implementation that benefit the poor and the environment. It aims to ensure that all this is achieved by enhancing the quality of its science work, increasing operational efficiency, building and maintaining strong partnerships, accelerating the use and impact of its research, and promoting greater cohesion, interdependence and alignment within the organization.

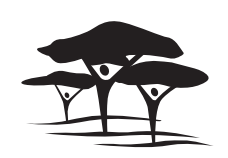

United Nations Avenue, Gigiri • PO Box 30677 • Nairobi, $00100 \cdot$ Kenya Telephone: +254207224000 or via USA +1 6508336645 Fax: +254207224001 or via USA +1 6508336646 Email: worldagroforestry@cgiar.org •www.worldagroforestry.org 